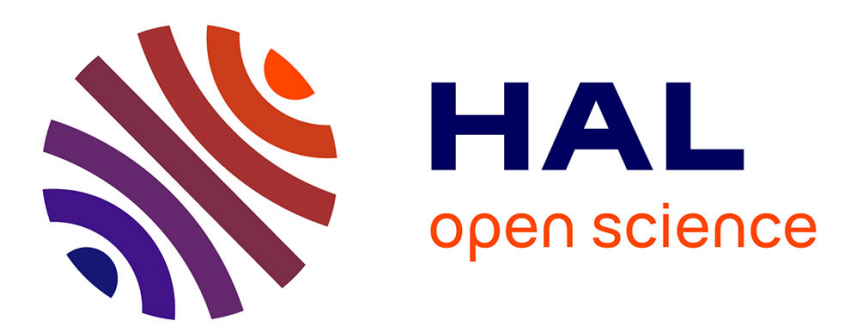

\title{
Forward model applied to channelized turbidite systems: a case study of the Benin major valley fill
}

Martin Lemay, Fabien Ors, Jean-Louis Grimaud, Jacques Rivoirard, Isabelle Cojan, Xavier Freulon

\section{- To cite this version:}

Martin Lemay, Fabien Ors, Jean-Louis Grimaud, Jacques Rivoirard, Isabelle Cojan, et al.. Forward model applied to channelized turbidite systems: a case study of the Benin major valley fill. EAGE Petroleum Geostatistics 2019, Sep 2019, Florence, Italy. hal-02331089

\section{HAL Id: hal-02331089 \\ https://hal.science/hal-02331089}

Submitted on 24 Oct 2019

HAL is a multi-disciplinary open access archive for the deposit and dissemination of scientific research documents, whether they are published or not. The documents may come from teaching and research institutions in France or abroad, or from public or private research centers.
L'archive ouverte pluridisciplinaire HAL, est destinée au dépôt et à la diffusion de documents scientifiques de niveau recherche, publiés ou non, émanant des établissements d'enseignement et de recherche français ou étrangers, des laboratoires publics ou privés. 
Martin Lemay*, Fabien Ors, Jean-Louis Grimaud, Jacques Rivoirard, Isabelle Cojan, Xavier Freulon MINES ParisTech, PSL University, Centre de Géosciences, Fontainebleau, France

* now at IFP Energies Nouvelles, Rueil-Malmaison, France

\section{Objectives}

Channelized turbidite systems are associated with extensive hydrocarbon reservoirs. Yet building realistic turbidite reservoir models is still a challenge. We take advantage of some similarities between fluvial and turbidite environments to transpose the Flumy model, initially dedicated to fluvial reservoirs (Lopez et al. 2008), to channelized turbidite systems by simulating the main processes at play in the submarine realm: channel lateral migration, avulsion, aggradation, overflowing flow striping, and sediment transport (Lemay et al 2018). A flow compatibe with the input channel geometry parameters is first built This Alow architecture of deposits, as well as their grain size. In this study, we present the application of Flumy to the case study of the Benin major valley.

\section{Turbidite Model Overview}

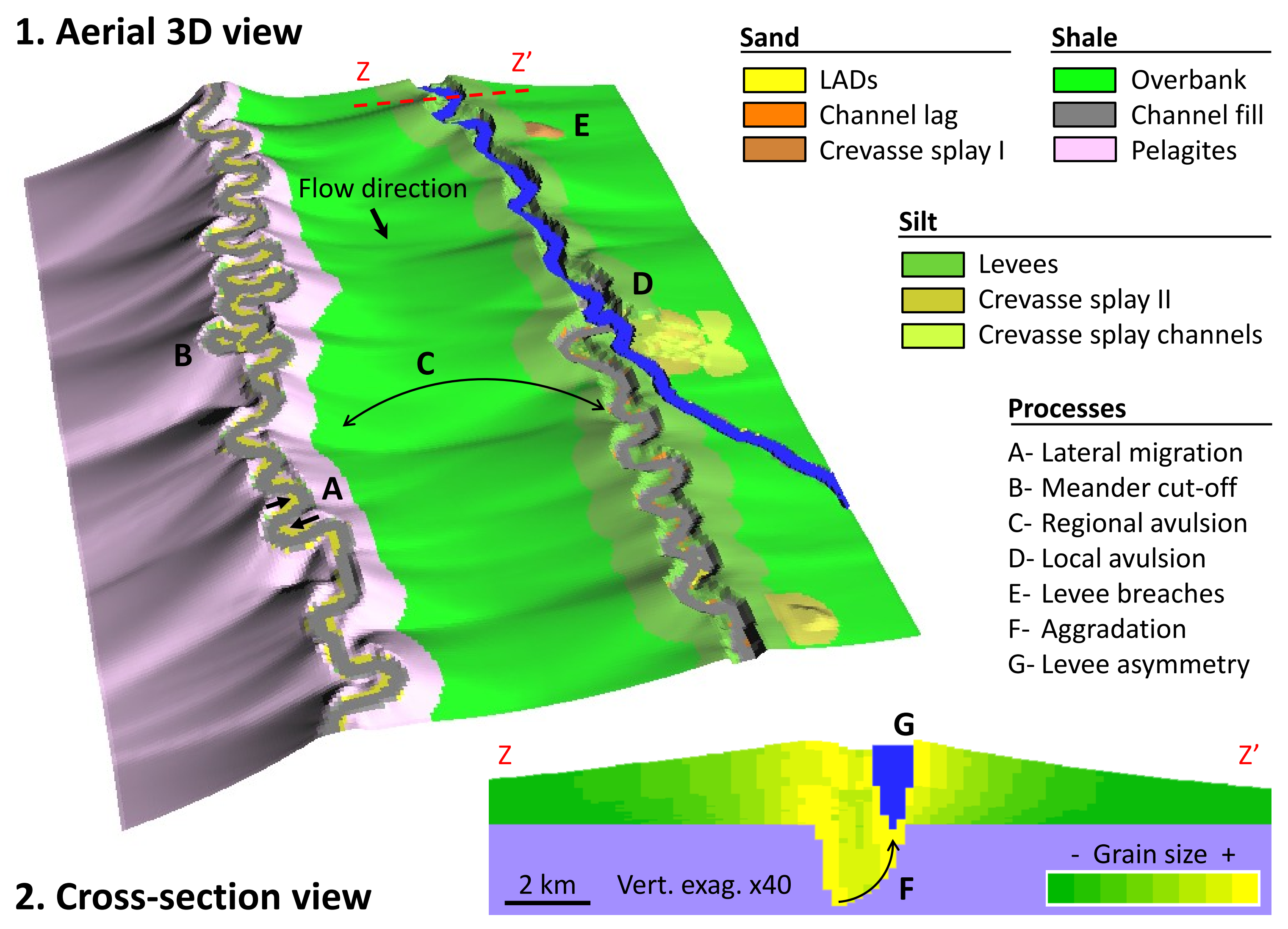

\section{Description of Main Processes}

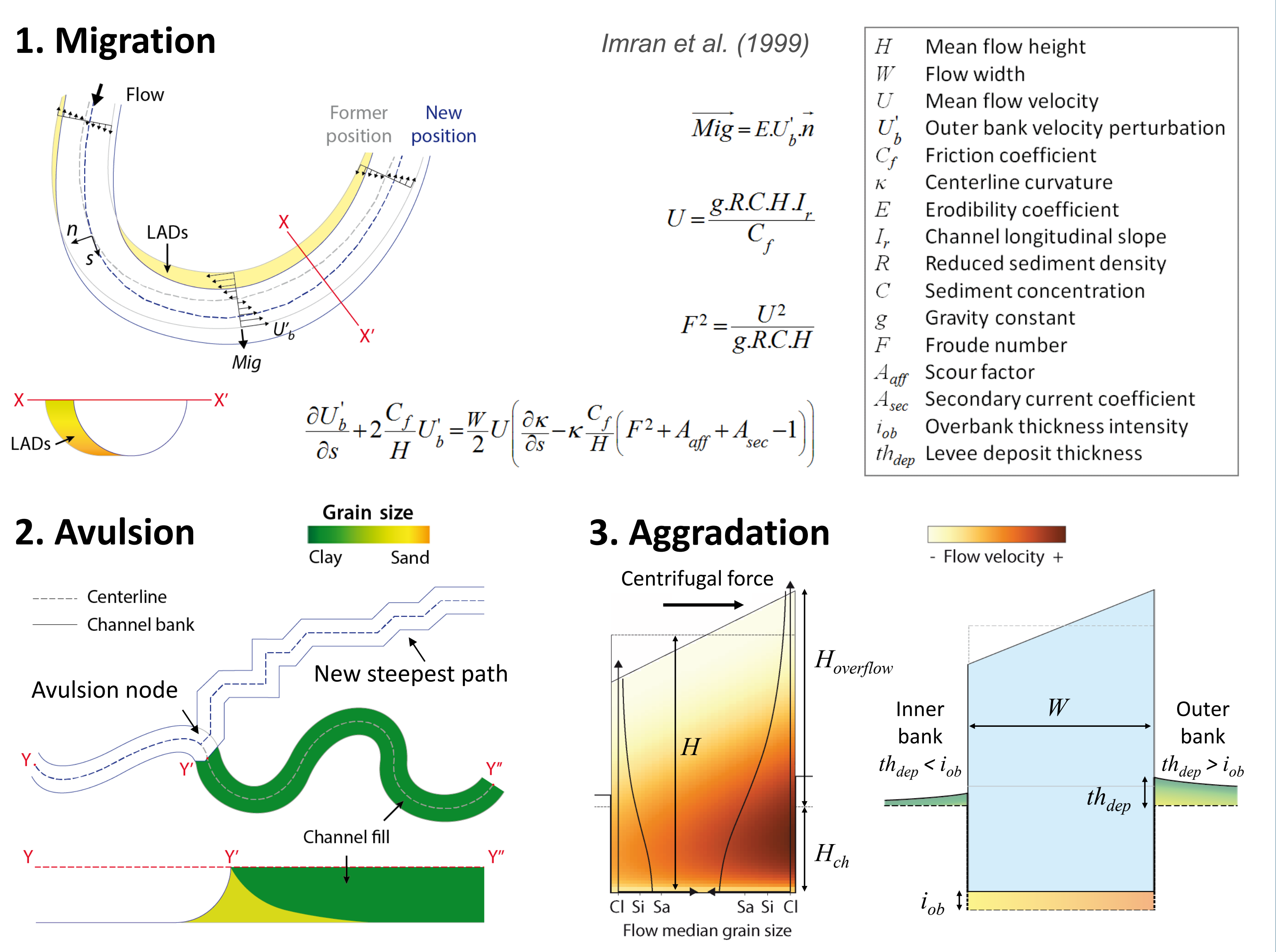

\section{Conclusion}

The simulation successfully reproduces the morphology of the valley, most of observed geomorphic features, and the various styles of filling architectures. It also results in a complex grain size arrangement which controls reservoir connectivity. This study shows that the model reproduces realistic stratigraphic architecture and can be used to simulate channelized turbidite reservoirs.

\section{Bibliography}

Deptuck, M. E. Sylvester, Z.. Pirmez, C., \& O'Byrne. C. (2007) Marine and Petroleum Geology 244(-9) $406-433$

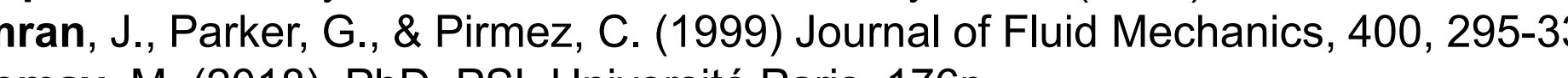

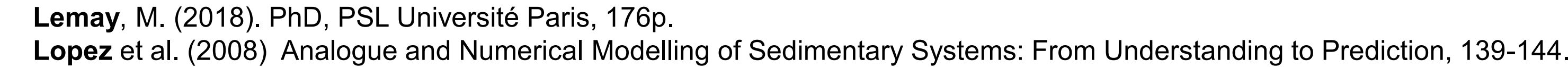

\section{Acknowledgments \\ This study has been conducted within the scope of the Flumy Research Program. The authors are grateful to ENGIE and ENI partners for support.

\section{Study Area \& Simulation Scenario}

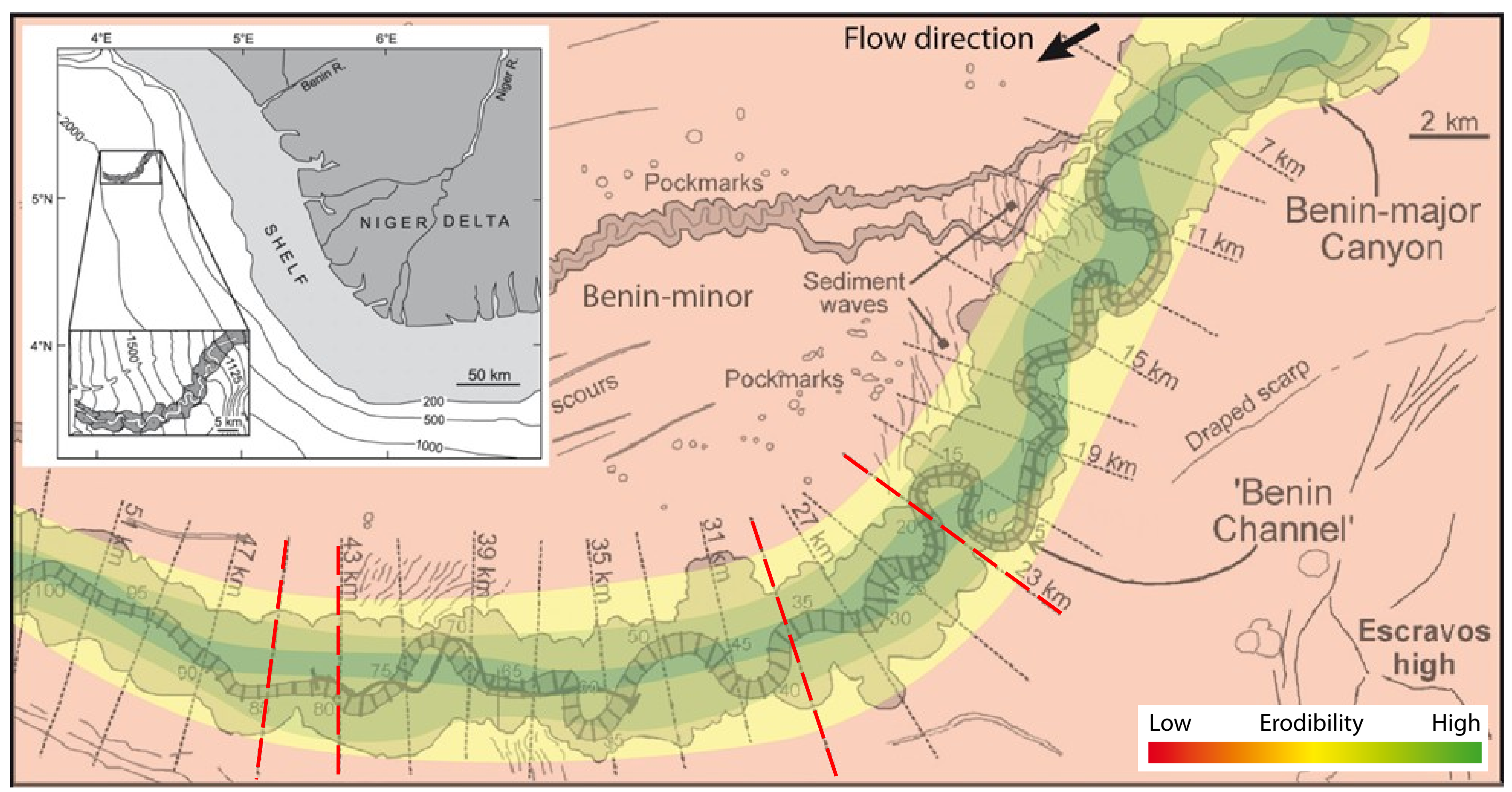

\begin{tabular}{|c|c|c|c|c|}
\hline & eome & try & Kinem & atics \\
\hline $\begin{array}{l}\text { W } \\
\text { (m) }\end{array}$ & $\begin{array}{l}\mathrm{H}_{\mathrm{ch}} \\
(\mathrm{m})\end{array}$ & $\begin{array}{c}\lambda \\
(\mathrm{m})\end{array}$ & $\begin{array}{c}\text { Aggrad } \\
\text { (m/k-iter) }\end{array}$ & $\begin{array}{c}\mathbf{T} \\
\text { iter }\end{array}$ \\
\hline $\begin{array}{l}750 \\
600\end{array}$ & $\begin{array}{l}35 \\
25\end{array}$ & $\begin{array}{l}3500 \\
3000\end{array}$ & $\begin{array}{l}+30 \\
+6\end{array}$ & $\begin{array}{l}3000 \\
2000\end{array}$ \\
\hline & & & +6 & 2500 \\
\hline & & & +4 & 2500 \\
\hline & & & -6 & 29000 \\
\hline 400 & 15 & 2000 & 0.5 & 1000 \\
\hline
\end{tabular}

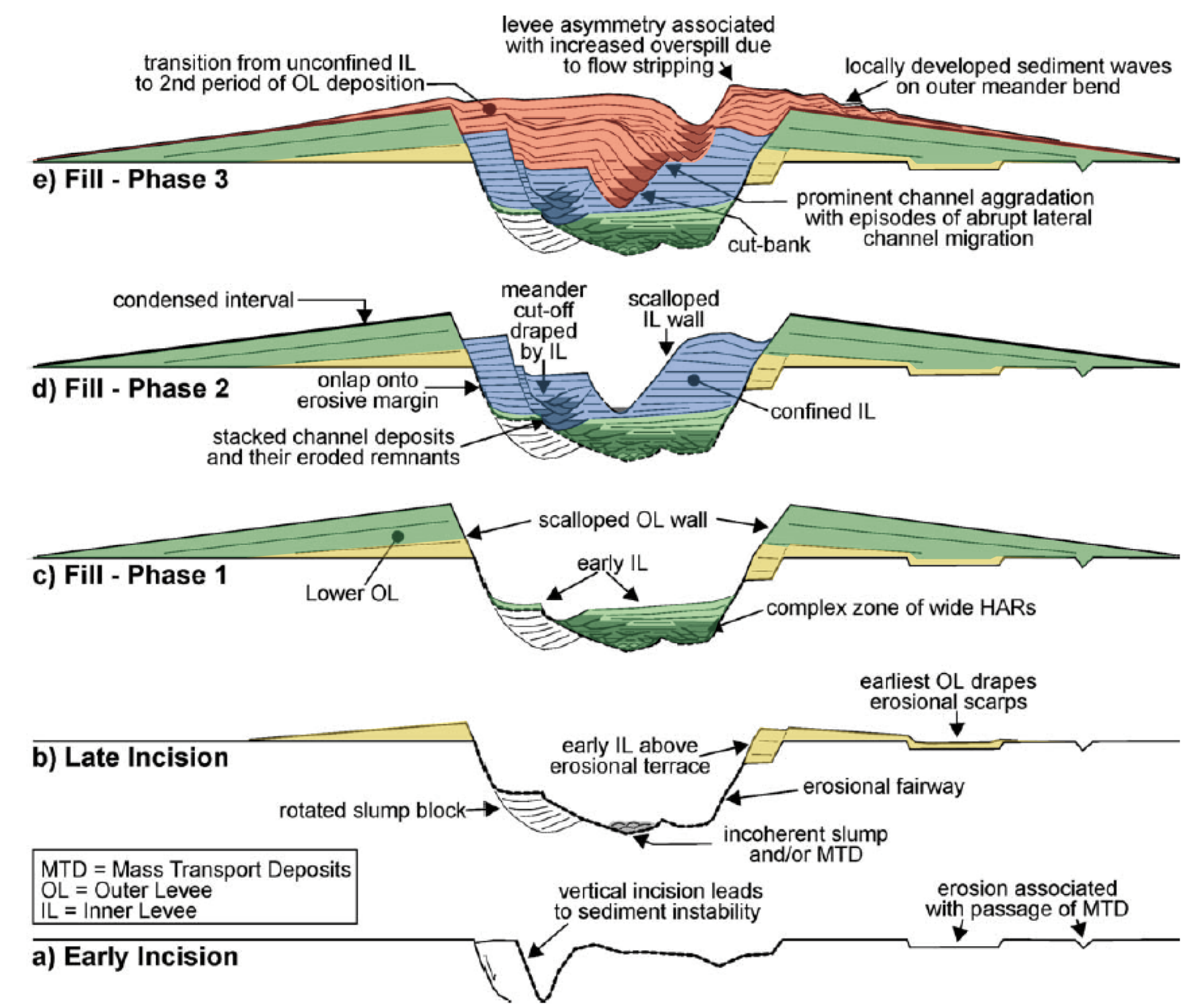

\section{Model Results}
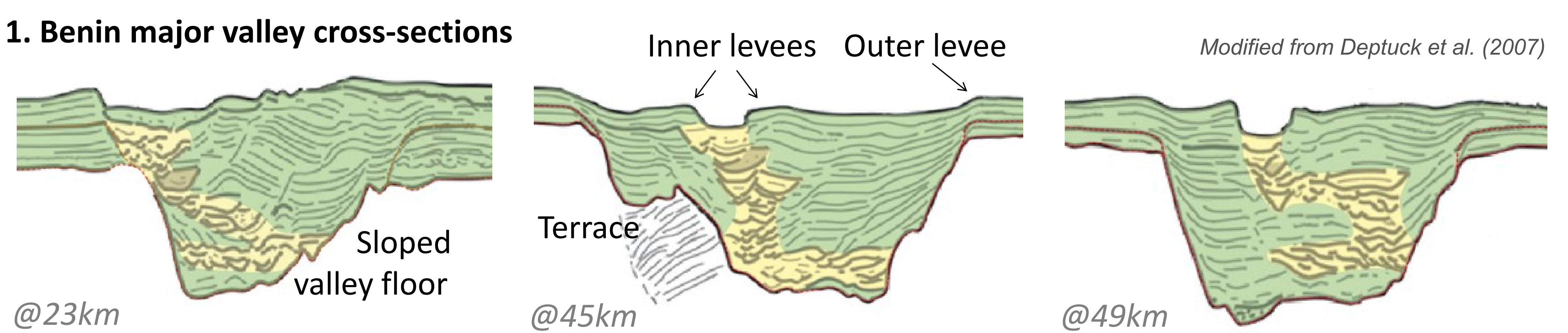

2. Flumy model cross-sections

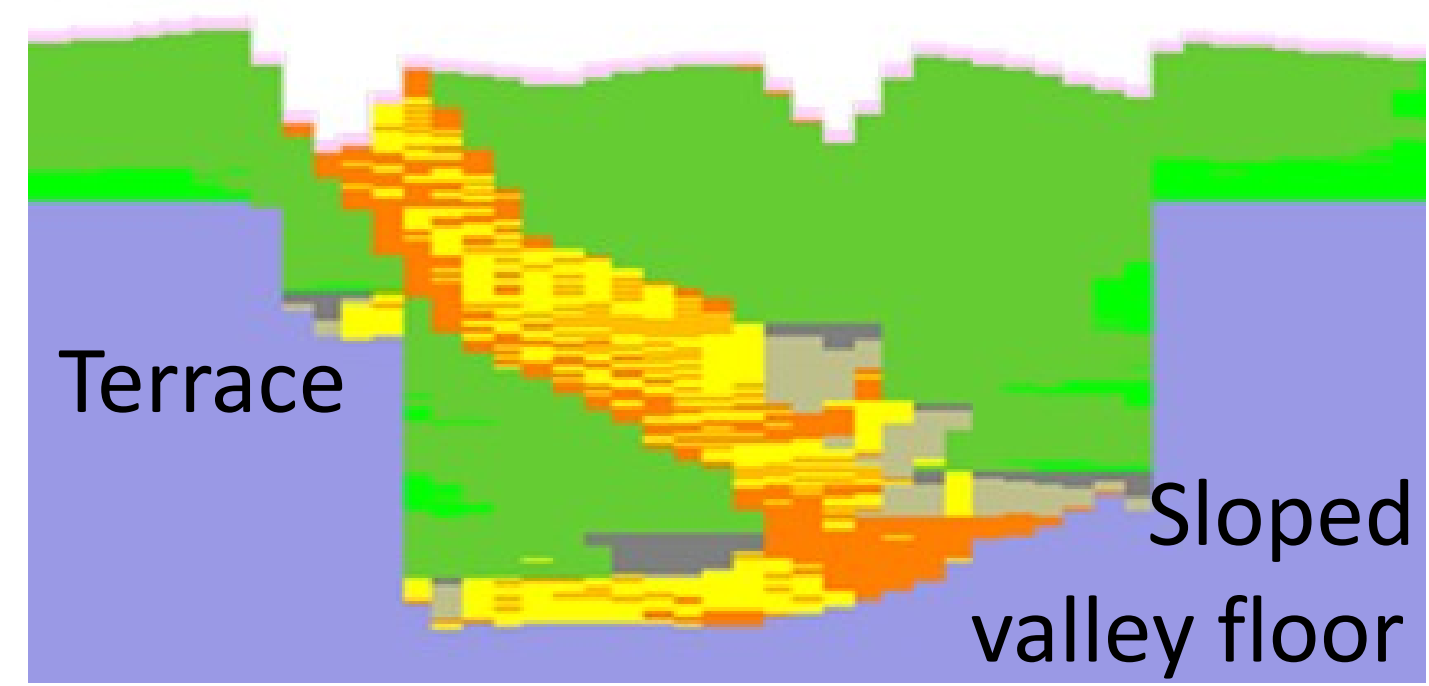

Inner levees Outer levee

Shale drape
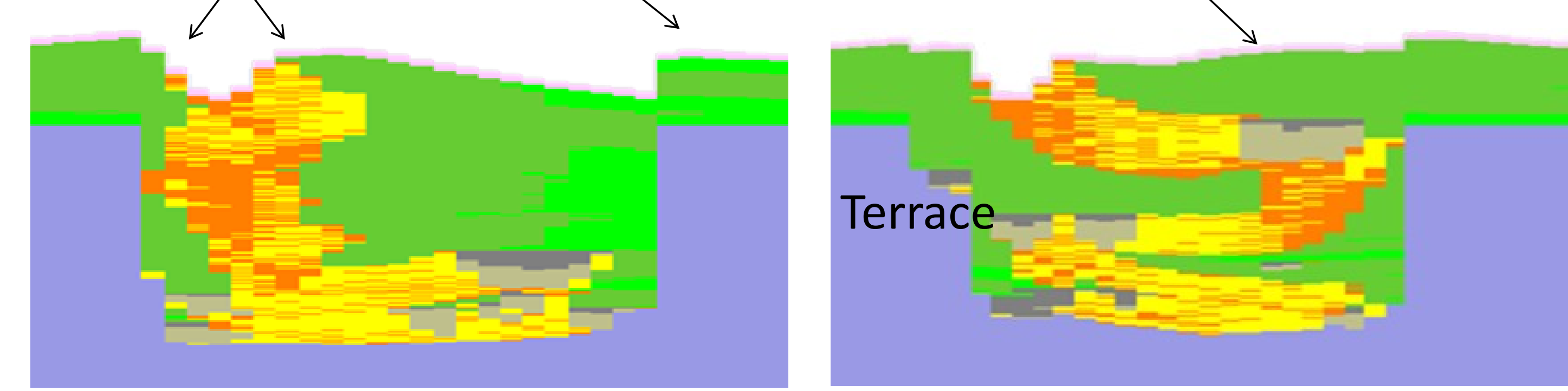

3. Complex grain size arrangement

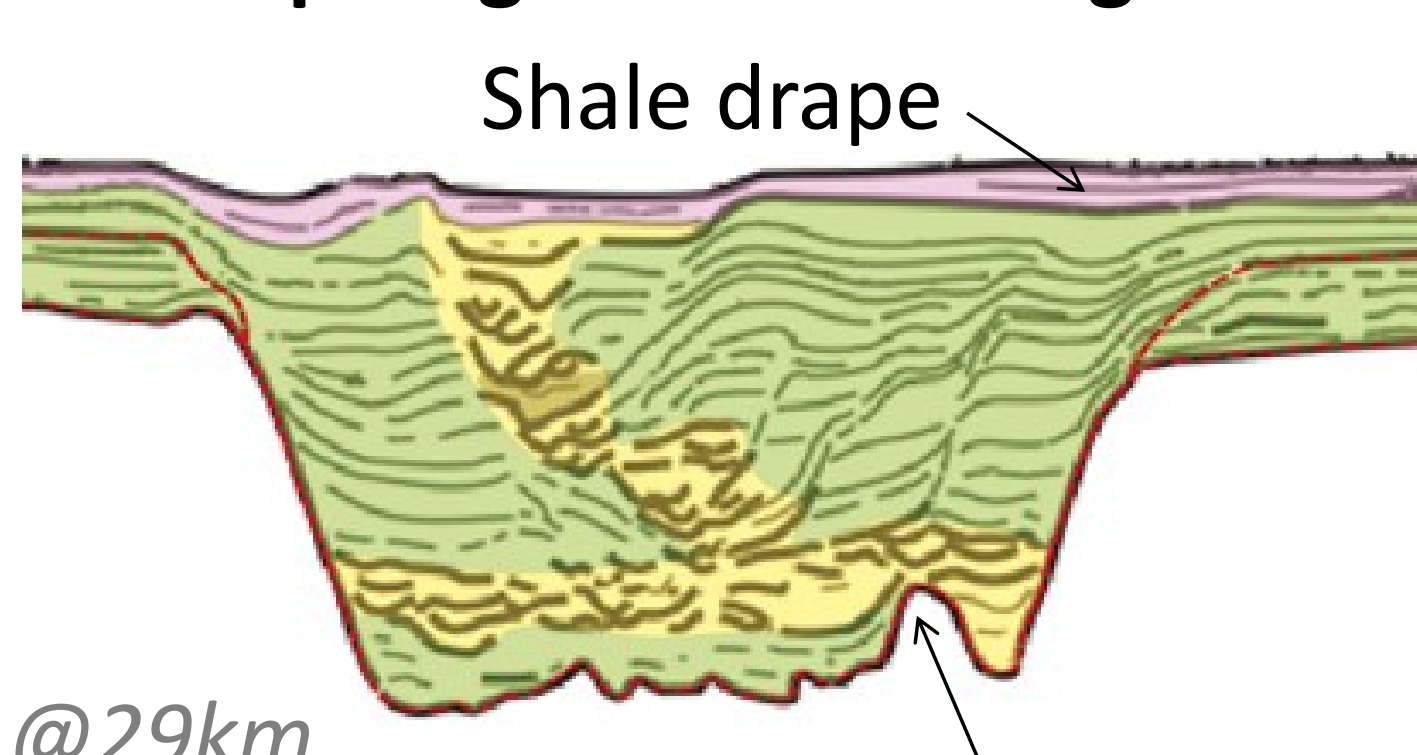

Topography high

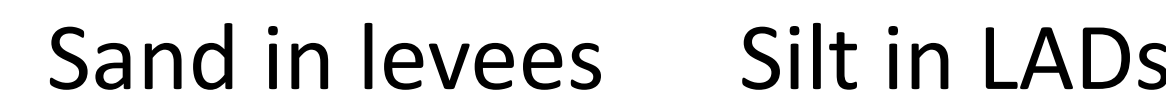

Shaly deposits

$\square$ Basement $\square$ Channel lag $\square$ Sand plug $\square$ Channel fill $\square$ LADs $\square$ Levees $\square$ Overbank $\square$ Pelagites $\square$ Clay $\mid$ Silt $\left.\right|_{\text {Sand }}$ Grain size Channelized deposits Unconfined deposits

\section{Contacts}

